\title{
Psychological Factors Related to Problematic Internet and Smartphone Use
}

\author{
Başak Türküler Aka', Sezen Kalecik², Burak Doğruyol ${ }^{3}$
}

Aka, B. T., Kalecik, S., \& Doğruyol, B. (2020). Psychological factors related to problematic internet and smartphone use. Nesne, 8(16), 1-15. DOI: 10.7816/nesne-08-16-01

Keywords
Problematic interne
use, problematic
smartphone use,
social anxiety
symptoms,
depression
symptoms, novelty
seeking

Anahtar kelimeler problemli internet kullanımı, problemli akıllı telefon kullanımı, sosyal kaygı semptomları, depresyon semptomları, yenilik arayışı

\begin{abstract}
In today's world, internet and smartphones have become essential parts of our lives. Besides their advantages, there are also some drawbacks regarding their usage. To investigate these drawbacks, problematic internet and smartphone use has been separately investigated within the scope of behavioral addiction. In parallel to this, present study aimed to investigate the relationship between problematic internet and smartphone use and psychological factors that were related to diverse addictive disorders in a Turkish sample. It was hypothesized that emotion regulation, self-control, depression and social anxiety symptoms, and novelty seeking would predict problematic internet and smartphone use. Data was collected from 337 adults between the ages of 18 and $66(M=28.86, S D=9.72)$. The results showed that although social anxiety and depression symptoms as well as low self-control predicted problematic internet and smartphone use; novelty seeking predicted only problematic smartphone use. Additionally, difficulties in emotion regulation did not predict problematic internet and smartphone use.
\end{abstract}

\section{Problemli İnternet ve Akılı Telefon Kullanımıyla İlişkili Psikolojik Etmenler \\ Öz}

Günümüzde internet ve akıllı telefon kullanımı hayatımızın önemli bir parçası haline gelmiştir. İnternet ve akıllı telefon kullanımının olumlu tarafları olduğu kadar, bazı olumsuz tarafları da bulunmaktadır. Bu olumsuzluklar, literatürde internet ve akıllı telefon kullanımı olmak üzere iki ayrı başlık altında ve davranışsal bağımlılık bağlamında ele alınmıştır. Literatüre paralel olarak bu çalışmada, problemli internet ve akıllı telefon kullanımı ile farklı bağımlılık türleriyle bağlantılı olduğu gösterilen psikolojik etmenler arasındaki ilişkinin incelenmesi amaçlanmıştır. Özellikle, duygu düzenleme, öz denetim, depresyon ve sosyal kaygı semptomları ve yenilik arayışının problemli internet ve akıllı telefon kullanımını yordayacağı düşünülmüştür. Çalışmaya 18 ile 66 yaş arasında $($ Ort. $=28.86, S S=9.72) 337$ yetişkin katılmıştır. Sonuçlar, depresyon ve sosyal kaygı semptomları ile düşük öz denetimin problemli internet ve akıllı telefon kullanımını yordadığını, yenilik arayışının ise sadece problemli akıllı telefon kullanımını yordadığını göstermiş̧tir. Bulgular ilgili yazın ışığında tartışılmış ve ileride yapılabilecek çalışmalar için öneride bulunulmuştur.
Article History

Arrived: 3 Ekim 2019

Revised: 18 Mart 2020

Accepted: 18 Mayls 2020
Author Note: The present research is a part of master's thesis which was conducted by the second author.

\footnotetext{
${ }^{1}$ Asissistant Professor, Bahçeşehir University, Department of Psychology, turkuleraka(at)gmail.com, ORCID: 0000-0002-5330-8485

${ }^{2}$ Clinical Psychologist, Istanbul, ORCID: 0000-0003-2409-7321

${ }^{3}$ Asissistant Professor, Altınbas University, Department of Psychology, ORCID: 0000-0002-3469-590X
} 
Internet and mobile phone use become an integrated part of our lives and they enrich daily life by providing immediate access to information and entertainment. In the last decade, internet and mobile phone use has considerably increased in Turkey. According to Turkish Statistical Institute (2015), 55.9\% of individuals who are older than 16 years of age used internet, and $69.5 \%$ of households had internet access, and $96.8 \%$ of them had at least one mobile phone. Additionally, the most common activity that Turkish people do on internet was to surf on social networking services.

The advantages of internet and smartphone use are undeniable, but also some drawbacks exist. Spending too much time on internet and smartphones, using them to alleviate anxiety, craving them when they are not available, using them as the only tools for socialization and entertainment are more likely to generate problems. Indeed, some studies found that problematic internet and smartphone use was negatively related to physical health (Demirci, Akgönül, \& Akpınar, 2015), social wellness (Davis, 2001), and mental health (Shepherd \& Edelmann, 2005). In parallel to these findings, many studies were conducted to investigate psychological causes and consequences of internet and mobile phone overuse within the frame of behavioral addiction (e.g., Beranuy, Oberst, Carbonell, \& Chamarro, 2009; Caplan, 2002; Roberts, Pullig, \& Manolis, 2015; Whang, Lee, \& Chang, 2003). In these studies, psychological problems such as attention deficit hyperactivity disorder, depression, social phobia (Yen, Ko, Yen, Wu, \& Yang, 2007), anxiety, and factors like compulsivity (Whang et al., 2003), impulsivity, insecure attachment style (Lin, Ko, \& Wu, 2011), harm avoidance, novelty seeking, and reward dependence (Ko et al., 2006) were found to be positively associated with problematic internet use. Additionally, studies also presented that there was a positive association between problematic smartphone use and depression, anxiety (Demirci et al., 2015), shyness, loneliness (Bian \& Leung, 2014), stress (Thomee, Harenstam, \& Hagberg, 2011), introversion, and emotional instability (Roberts et al., 2015).

In literature, variety of terms have been used to define problems related to internet use such as internet addiction (Young, 1996), pathological internet use (Davis, 2001), problematic internet use (Caplan, 2002), internet over-users (Whang et al., 2003), internet addictive behavior (Li \& Chung, 2006), compulsive internet use (Meerkerk, van den Eijnden , Franken, \& Garretsen, 2010), and excessive internet use (Weinstein \& Lejoyeux, 2010). The Diagnostic and Statistical Manual of Mental Disorders (5th ed.; DSM-5; American Psychiatric Association, 2013) covers internet Gaming Disorder as a problematic part of excessive internet use. However, it can be considered as a subcategory or a more specific form of excessive internet use since there are many other uses of internet such as watching video, academic or employment related effort, social media, and blogging. To underline this difference, Davis (2001) suggested two different terms as "Specific Pathological Internet Use" and "Generalized Pathological Internet Use". The former one includes dependence on a content specific activity such as online gambling, shopping, gaming and so on that is mostly offered by internet. Latter one includes dependence on internet itself and excessive internet use in different fields, which may also be time consuming. Additionally, Günüç (2015) stated that internet gaming addiction and internet addiction are strongly related. Therefore, it seems that there are no exact diagnostic criteria that is agreed upon in the literature.

Smartphones, on the other hand, provide an opportunity for a wide array of applications such as gaming, social media, mp3, 3G or 4G connectivity, navigation, internet, and so on. With the growing use of smartphones, also some concerns have been arisen about the excessive use of them and researchers have 
focused on investigating the factors and results that are associated with problematic smartphone use over the past several years (Bian \& Leung, 2014; Park \& Lee, 2012; Roberts et al., 2015). Smartphone addiction can be defined as a reduced control over being involved in smartphone use, craving for it when it is not used, and excessive use of it despite of its negative effects on person's life within the frame of behavioral addiction (Kwon et al., 2013).

In order to understand the etiology of problematic internet and smartphone use, studies have emphasized on revealing potential links between psychological well-being, personality characteristics and problematic behaviors (e.g., Caplan, 2003; Davis, 2001; Demirci et al., 2015; Ko et al., 2006; Morrison \& Gore, 2010; Young, 1996). In one of these studies, Thomee et al. (2011) stated a positive association between cell phone overuse, depression and sleep problems. Davis (2001) also suggested that to be able to avoid negative cognitions, substantial problems like depression might lead individuals to use internet excessively. Similarly, smartphone overuse may provide a way for stressed and depressed individuals to manage their emotions (Karaaziz \& Keskindağ, 2015).

Moreover, internet might serve as a function of regulating social fears and reducing stress related to these fears (Caplan, 2002; 2003). In one study (Ko, Yen, Chen, Yeh, \& Yen, 2009), it was presented that the emergence of internet overuse was predicted by social anxiety. Also, a positive association between social phobia symptoms and problematic smartphone use was showed in a study with Turkish college students (Darçın, Noyan, Nurmedov, Yılmaz, \& Dilbaz, 2015).

A study conducted with adolescents in Korea by Yu, Kim, and Hay (2013) and a study conducted with university students in Turkey by Oktan (2011) presented high correlation between difficulties in emotion regulation and problematic internet use. It is also possible that internet addiction could serve as an aid for regulating emotions and coping with stress according to self-medication model as in other addictions, which can be seen as a short-term reward (Shepherd \& Edelmann, 2005).

Self-control may be regarded as another important factor related to excessive internet and smartphone use. It was stated that online game addiction was predicted by low level of self-control (Kim, Namkoong, Ku, \& Kim, 2008). In one study (Akın, Arslan, Arslan, Uysal, \& Sahranç, 2015), it was shown that problematic internet use was negatively predicted by poor self-control and self-management. Kim and Lee (2012) also depicted that there was a negative correlation between smartphone addiction and self-control in a university sample.

Another psychological factor related to excessive internet and smartphone use is novelty seeking. In a study with Taiwanese sample, it was shown that adolescences with high levels of novelty seeking were more inclined to engage in excessive internet and substance use (Ko et al., 2006). A study conducted with Turkish university students also presented that there was a positive association between higher scores on novelty seeking and internet dependence (Dalbudak et al., 2013).

In the light of previous literature, current study aimed to investigate a group of potential predictors as difficulties in emotion regulation, depression, social anxiety symptoms, self-control, and novelty seeking for problematic internet and smartphone use in a Turkish sample. It was hypothesized that problematic internet and smartphone use would correlate. It was also expected that higher levels of depression, higher 
levels of social anxiety symptoms, higher levels of difficulties in emotion regulation, higher levels of novelty seeking, and lower levels of self-control would predict higher levels of problematic internet and smartphone use.

\section{Method}

\section{Participants}

The sample consisted of 348 participants who completed a battery of questionnaires and an informed consent. However, those who failed to respond adequately to the questionnaires were excluded from the analyses, therefore the final number was 337 participants (96 males, 241 females) who were using internet and smartphones and over the age of 18 . The age range was between 18 and $66(M=28.86, S D=9.72)$. The majority of the participants $(\% 67.2)$ had a university degree, $\% 23$ of them had a master or doctoral degree, $\% 1.2$ of them were primary school graduates, $\% 2.3$ of them were secondary school graduates, and $\% 6.3$ of them were high school graduates. Of the participants, $191(\% 56.7)$ were employed. ${ }^{4}$ Most common aim to use smartphone was to use social network sites $(n=88, \% 26.1)$, followed by internet access $(n=84, \% 24.9)$, testing $(n=63, \% 18.7)$, and voice call $(n=57, \% 16.9)$. Furthermore, most usage of internet was to access social network sites $(n=148, \% 43.9)$, followed by search information $(n=79, \% 23.4)$, and entertainment $(n$ $=58, \% 17.2)$.

\section{Measures}

Demographic Form: Participants fulfilled a demographic form including questions about age, gender, education level, and current employment status. Besides, participants were asked two different questions to report their most dominant aim to use smartphone and internet.

Problematic Internet Usage Scale: Problematic Internet Usage Scale (Ceyhan, Ceyhan \& Gürcan, 2007) is a 33-item, five-point Likert-type self-rating scale. The scale aims to determine the intensity of internet use within a scope of healthy and unhealthy conditions. The scale has three subscales as negative consequences of the internet, social benefit/social comfort, and excessive use. The total score in the scale can vary between 33 and 165 and higher scores point out more problematic internet use. The scale shows considerably high internal consistency (Cronbach's $\propto=.94)$ as well as a good retest $(\propto=.81)$ and split half reliability $(\propto=.83)$. In the present study, Cronbach's alpha of the scale was .84.

Smartphone Addiction Scale: It was developed by Kwon et al., (2013) and it aims to specify the level of individual's smartphone addiction. It has 33 items, six-point Likert scale and it includes six subscales as: 1) daily life disturbance, 2) positive anticipation, 3) withdrawal, 4) cyber-space oriented relationship, 5) overuse, and 6) tolerance. The Turkish adaptation of the scale was conducted by Demirci, Orhan, Demirdas, Akpinar and Sert (2014) with 301 university students and Cronbach's alpha was .95. The alpha coefficient for the present study was .95 .

Difficulties in Emotion Regulation Scale: The scale was developed by Gratz and Roemer (2004) and it consists of 36 items and it aims to evaluate different domains of emotion regulation. Higher scores point out higher levels of emotion regulation difficulties. It is assessed on a five-point Likert scale and total score in

\footnotetext{
${ }^{4}$ Two independent sample t-tests were conducted on problematic internet and smartphone use to test the potential effects of working conditions. Both tests revealed nonsignificant results $(p$ 's $>.05)$.
} 
the scale can vary between 36 and 180. The scale was adapted to Turkish by Ruganc1 and Gençöz (2010). The adapted version of the scale has 35 items and Cronbach's alpha was .94. The alpha coefficient for the present study was .92 .

The Liebowitz Social Anxiety Scale: The Liebowitz Social Anxiety Scale developed by Liebowitz (1987) is a 24-item scale and it aims to evaluate difficulties that people with social phobia experience under a broad range of social circumstances. The scale has two subscales and respondents are asked to rate each item individually both for these two subscales; "fear or anxiety" and "avoidance behavior". It is assessed on a four-point scale and higher scores indicate higher levels of social anxiety. The Turkish adaptation of the scale was carried out by Soykan, Devrimci-Özgüven and Gençöz (2003) and Cronbach's alpha was .95. The alpha coefficient for the present study was .95 .

Beck Depression Inventory: Beck Depression Inventory (Beck, Ward, Mandelson, Mock, \& Erbaugh, 1961) has 21 items and the aim of the scale is to evaluate severity of depression symptoms. Possible total score of the scale ranges between 0 and 63. The Turkish adaptation of Beck Depression Inventory was carried out by Hisli (1988) and it was stated the scale has similar psychometric properties with the original version. The alpha coefficient for the present study was .87 .

Self-control scale: Self-control scale (Tangney, Baumeister, \& Boone, 2004) consists of 36 items and it aims to determine the level of individual's self-control. It is assessed on a five-point Likert scale and the possible score ranges between 36 and 180. Higher scores present higher levels of self-control. The alpha coefficient of the scale was .89. The Turkish translation of the scale was conducted in the present study. Necessary permissions were granted to use the scale. First, two experts (social and clinical psychologist) translated the scale into Turkish. Then, a bilingual expert (developmental psychologist) conducted the backtranslation. Finally, experts finalized the translation by discussing potential problems of the final form. Selfcontrol is shown to be a universal construct depending on the findings on adults (Rothbaum, Weisz, \& Snyder, 1982) and children (Michel, 2014). Besides, self-control is a fundamental component of executive function of the self not only for human beings but also for nonhuman primates (Addessi, Paglieri, \& Focaroli, 2011; Rosati, Stevens, Hare, \& Hauser, 2007). Self-control scale as a self-report measure have shown to be a universally (e.g., across cultures and genders) reliable and valid construct in numerous studies (see Boyraz, Zhu, \& Aarstad-Martin, 2019; Li and Vazsonyi, 2019; Manapat, Edwards, MacKinnon, Poldrack, \& Marsch, 2019). The alpha coefficient for the present study was .84.

Novelty Seeking Scale on Temperament and Character Inventory: The Temperament and Character Inventory (Cloninger et al., 1994) was based on Cloninger's psychobiological model of personality. It has 240 items and respondents are asked to answer true-false questions. Novelty Seeking scale is one of the four temperament dimensions that is assessed in the inventory. It has 40 items and aims to measure the level of individual's novelty seeking. Turkish adaptation of the scale was carried out by Köse et al., (2004) and the results showed that psychometric properties of TCI and its dimensions are adequate to use in Turkish sample. The alpha coefficient for the present study was .72.

\section{Procedure}

Ethical approval for the data was granted by the Bahçeşehir University Scientific Research and Publications Ethics Committee. Data collection was carried out between March-April 2016. A part of the 
data was collected throughout social media like Facebook or Twitter in which participants filled out the questionnaires online $(n=166, \% 49.3)$. Another part of the data was collected during face-to-face interviews ( $n=171, \% 50.7)$ by using convenience sampling. A form supported by Google Forms service (https://docs.google.com/forms) was used to collect online data. It took 40-50 minutes to fill out the questionnaires. The data analysis showed that there were no significant differences between these two methods of recruitment in terms of study variables.

\section{Data analyses}

In order to test hypotheses, a multiple regression model was constructed. In this model, problematic internet and smartphone use were entered to regression equation as dependent variables. The independent variables; difficulties in emotion regulation, social anxiety, novelty seeking, depression, and self-control were entered in a single block. Age was used as controlling variable.

Regression analysis was tested by fully saturated regression model with observed variables using Lisrel 8.51. A fully saturated regression model was preferable since it allows researchers to consider intercorrelation among independent variables, measurement errors associated with each variable, and intercorrelations among dependent variables. Besides, maximum likelihood (ML) estimation technique approach provides more flexibility for assumptions such as multicollinearity as compared to the least squares (LS) method used in multiple regression analyses.

\section{Results}

Descriptive information of study variables and group comparisons based on gender is displayed in Table 1. As can be seen, there was no gender difference among study variables.

Table 1

Descriptive Information of the Measures

\begin{tabular}{cccccccc}
\hline & \multicolumn{2}{c}{ Overall } & \multicolumn{2}{c}{ Female } & \multicolumn{3}{c}{ Male } \\
\hline Measures & $M$ & $S D$ & $M$ & $S D$ & $M$ & $S D$ & $t$ \\
\hline PIUS & 65.69 & 21.25 & 65.45 & 21.01 & 66.30 & 21.94 & -0.33 \\
SAS & 75.33 & 25.75 & 75.49 & 25.34 & 74.93 & 26.88 & 0.18 \\
DERS & 81.47 & 19.12 & 81.95 & 19.10 & 80.27 & 19.33 & 0.73 \\
LSAS & 89.39 & 24.38 & 90.88 & 24.20 & 85.64 & 24.53 & 1.79 \\
BDI & 10.26 & 8.03 & 10.11 & 7.44 & 10.62 & 9.37 & -0.52 \\
SCS & 120.17 & 15.56 & 120.34 & 15.71 & 119.77 & 15.27 & 0.30 \\
NSS & 19.22 & 5.67 & 19.13 & 5.52 & 19.45 & 6.04 & -0.47 \\
\hline
\end{tabular}

Note. PIUS: Problematic Internet Usage Scale, SAS: Smartphone Addiction Scale, DERS: Difficulties in Emotion Regulatin Scale, LSAS: Liebowitz Social Anxiety Scale, BDI: Beck Depression Inventory, SCS: Self-Control Scale, NSS: Novelty Seeking Scale.

A simple bivariate correlation test was performed. A summary of the result is shown in Table 2 . Bivariate correlation revealed significant relationships between age and study variables. Older participants in our sample were more likely to report less severe symptoms of problematic internet and smartphone use. Thus, partial correlation matrix (by controlling the effects of age) was used for further regression analysis. Results of bivariate correlations also revealed that those who reported higher levels of problematic internet 
use were more likely to be addicted to smartphone. Considering the strong relationship between dependent variables, problematic internet and smartphone use were freely correlated in regression analysis.

Table 2

Bivariate Correlations among Study Variables

\begin{tabular}{|c|c|c|c|c|c|c|c|}
\hline Measures & 1 & 2 & 3 & 4 & 5 & 6 & 7 \\
\hline \multicolumn{8}{|l|}{ Age } \\
\hline PIUS & $-.239^{* *}$ & & & & & & \\
\hline SAS & $-.248^{* *}$ & $.715^{* *}$ & & & & & \\
\hline DERS & $-.156^{* *}$ & $.434^{* *}$ & $.382^{* *}$ & & & & \\
\hline LSAS & -.050 & $.391^{* *}$ & $.320^{* *}$ & $.403^{* *}$ & & & \\
\hline BDI & -.022 & $.411^{* *}$ & $.350^{* *}$ & $.536^{* *}$ & $.311^{* *}$ & & \\
\hline SCS & $.263^{* *}$ & $-.455^{* *}$ & $-.389^{* *}$ & $-.459^{* *}$ & $-.253^{* *}$ & $-.341^{* *}$ & \\
\hline NSS & $-.178^{* *}$ & $.119^{*}$ & $.198^{* *}$ & .054 &.-105 & .014 & $-.465^{* *}$ \\
\hline
\end{tabular}

Note. PIUS: Problematic Internet Usage Scale, SAS: Smartphone Addiction Scale, DERS: Difficulties in Emotion Regulation Scale, LSAS: Liebowitz Social Anxiety Scale, BDI: Beck Depression Inventory, SCS: Self-Control Scale, NSS: Novelty Seeking Scale.

Note. ${ }^{*} p<0.05, * * p<0.01$

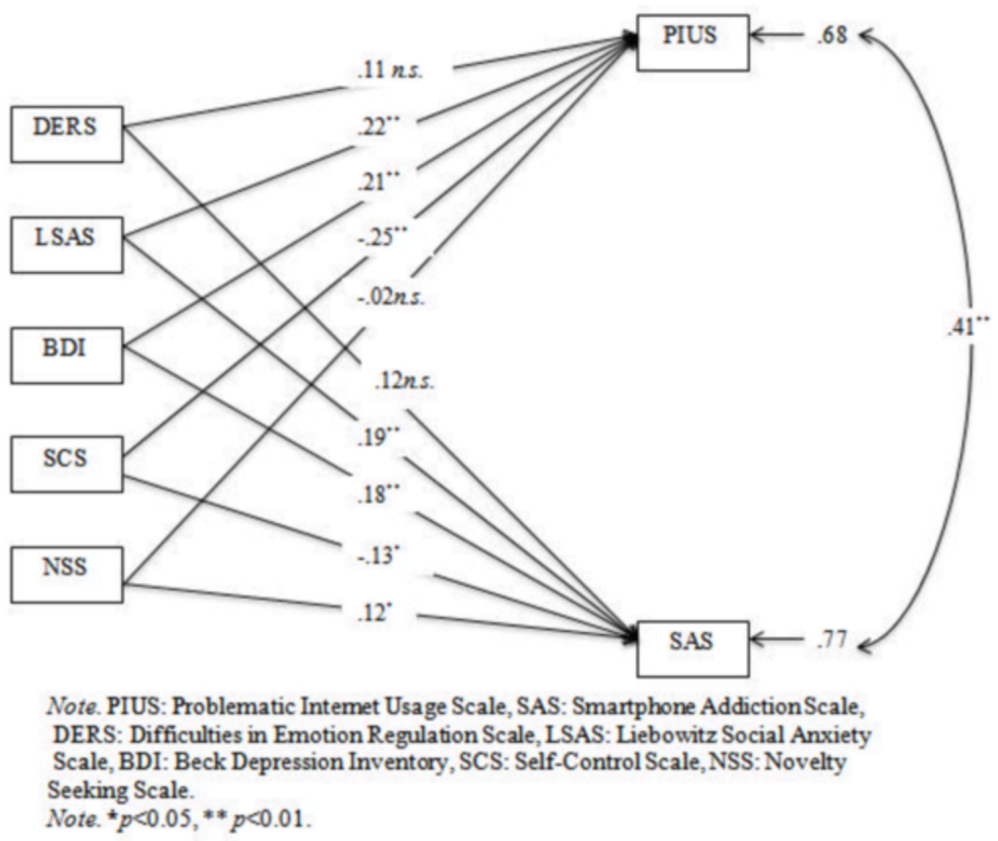

Figure 1. Multiple Regression Analysis Results

A multiple regression analysis was performed after controlling for the effects of age. A summary of the results is displayed in Figure 1. After controlling for the effects of age, social anxiety, depression symptoms, and self-control had significant effects on problematic internet use. Accordingly, higher levels of social anxiety, and depression symptoms and lower levels of self-control were related to higher levels of problematic internet use. Results revealed a slightly different pattern for smartphone addiction suggesting that as the level of social anxiety and depression symptoms, and novelty seeking increase, the level of smartphone addiction increase. Besides, lower levels of self-control were related to higher levels of smartphone addiction. 


\section{Discussion}

The present study examined the relationship among various psychological factors and problematic internet and smartphone use. Specifically, the contribution of the difficulties in emotion regulation, depression, and social anxiety symptoms, self-control, and novelty seeking in problematic internet and smartphone use was investigated in a Turkish sample. Additionally, the effect of age was controlled to avoid any confounding results considering the age range of the study.

Results related to age, in line with current literature (e.g., Bakken, Wenzel, Gotestam, Johansson, \& Oran, 2009; Bergmark, Bergmark, \& Findahl, 2011; Bianchi \& Phillips 2005), presented that age was negatively correlated with problematic internet and smartphone use. This finding may be related to the fact that most of the studies about problematic internet use was conducted with university students; a sample who have more spare time and easy access to internet (Chou \& Hsiao, 2000; Shepherd \& Edelman, 2005). A decline in the problematic use of smartphones as participants get older may be due to the fact that older people become less interested and enthusiastic about new technologies.

In terms of gender, results revealed that there were no significant differences between male and female participants in terms of problematic internet and smartphone use. In literature, there was no consensus on the effect of gender on these areas. While some studies claimed that males are more inclined to have problematic internet use than females (Çuhadar, 2012; Lin et al., 2011), others (Ni, Yan, Chen, \& Liu, 2009; Odac1, 2011) asserted that gender had no effect on problematic internet use as in line with the current study. Similarly, some studies pointed out that there were no gender differences on excessive smartphone use (Bianchi \& Phillips, 2005; Thomee et al., 2011), whereas others (Beranuy et al., 2009, Demirci et al., 2015) depicted that females had more tendency to engage in problematic smartphone use. The findings related to gender differences in the current study imply that easy access to internet and smartphones in today's world may pose a risk for both genders in the same vein. Additionally, other factors to use internet and smartphones such as social networking, voice calling, searching, and gaming and spending spare time rather than gender might create difference on problematic internet and smartphone use as suggested by Young (1996) and Demirci et al. (2014).

After controlling the effect of age, results of regression analysis on problematic internet and smartphone use showed that participants who had higher levels of depression, and social anxiety symptoms and lower levels of self-control engage in more problematic internet use as parallel to previous findings (Demirci et al., 2015; Kim et al., 2008; Ko et al., 2009; Yen et al., 2007).

In terms of depression symptoms, cognitive-behavioral model offers an explanation for problematic internet use (Caplan, 2010; Gámez-Guadix, Orue, \& Calvete, 2013; Gámez-Guadix, 2014). According to this model, there are four main components; (1) the assumption that internet-related relationships are safer, easier, more convenient, and less threatening compared to real life interactions (Meerkerk et al., 2010; Caplan \& High, 2011; Kim \& Davis, 2009), (2) using internet as a way of mood regulation to reduce negative feelings and anxiety (Spada, Langston, Nikcevic', \& Moneta, 2008), (3) inadequate self-regulation in which the person loses the control of behaviors and cognitions connected to the internet (LaRose, Lin, \& Eastin, 2003), and (4) as a consequence of dysfunctional internet use; the emergence of adverse effects in personal, social, academic, and work life (Caplan, 2010; Munoz-Rivas, Fernandez, \& Gámez-Guadix, 2010). 
This model also states that having prior depressive symptoms can be evaluated as a risk factor that constitutes a predisposition for an individual to face with problematic internet use (Davis, 2001). In other words, individuals who have depressive symptoms may use internet as a way to reduce emotional distress or avoid other problems, which may increase the tendency of engaging in problematic internet use (Davis, 2001). In terms of the direction of the relationship, the results of the current study presenting that individuals with higher levels of depressive symptoms engaged in more problematic internet use provided a support for this model. In line with the explanations of the cognitive-behavioral model for problematic internet use (Caplan, 2010; Gámez-Guadix et al., 2013; Gámez-Guadix, 2014), similar mechanisms may work for the problematic smartphone use as well. Individuals with depressive symptoms may use smartphones as a distraction to reduce emotional distress and escape from other problems, which as a consequence may maximize the probability of problematic smartphone use as in problematic internet use (Davis, 2001).

Social anxiety has been evaluated as one the risk factors for the emergence of problematic internet use (Caplan, 2007; Erwin, Turk, Heimberg, Fresco, \& Hantula, 2004; McKenna \& Bargh, 2000). The suggested mechanism of the relationship between social anxiety and problematic internet use was through the safety behaviors (Erwin et al., 2004; Shepherd \& Edelmann, 2005). Safety behaviors in social anxiety temporarily alleviate anxiety but in the long run they prevent individuals from seeing that they are exaggerating the possibility of negative evaluation and undermining their social ability (Alden \& Bieling, 1998; Rapee \& Heimberg, 1997). It has been stated that online interactions may be regarded as safety behaviors in which threat perception and related anxiety is minimized (Lee \& Stapinski, 2012). By that way, if reduced anxiety and successful online communications are linked to the characteristics of the internet like being anonymous (Clark \& Wells, 1995; Erwin et al., 2004; McKenna, Green, \& Gleason, 2002), it may create an avoidance cycle that leads to the emergence of problematic internet use (Andersson, 2009; Erwin et al., 2004; Sheeks \& Birchmeier, 2007; Shepherd \& Edelmann, 2005). In line with this, the results of the current study also presented a relation between social anxiety and the internet in which higher levels of social anxiety symptoms predicted higher levels of problematic internet use.

For social anxiety symptoms, the same avoidance mechanism for problematic internet use (e.g., Lee \& Stapinski, 2012) may be responsible for the possible risk of addiction to smartphone use (Darçin et al., 2016). Additionally, it was stated that online socialization may reduce the fear of showing bodily clues of physiological arousal symptoms, which constitutes the base of social anxiety symptoms (Darçın et al., 2016). Parallel to this, the results of our study presented that higher levels of social anxiety symptoms predicted more problematic smartphone use.

Regarding self-control, lower levels of self-control were associated with higher levels of problematic internet and smartphone use, as has been suggested in previous research (Akın et al., 2015). For individuals who have difficulties in self-control area, it would be difficult to control themselves, especially considering the multiple facets of using smartphones and internet use. Tangney et al., (2004) suggested that higher levels of self-control were related to psychological health. Therefore, enhancing self-control in individuals who have problematic internet and smartphone use complaints may be beneficial, especially regarding the limits of the time spent on the internet and smartphone use.

On the contrary to the expectations, in the current study novelty seeking did not predict problematic internet use. On the subject of novelty seeking in relation to problematic internet use, there is no agreement 
on the literature. Although, in a study (Cho, Kim, Kim, Lee, \& Kim, 2008) it was stated that problematic internet users were more likely to have lower scores on novelty seeking, most of the studies presented that higher scores of novelty seeking was related to excessive internet use (Dalbudak et al., 2013; Ko et al., 2006) and other types of addiction (Janiri, Martinotti, Dario, Schifano, \& Bria, 2007). Different findings regarding the association between novelty seeking and problematic internet use in the literature may be related to the preferences of internet use. Individuals who use internet just for searching or entertainment may not seek novelty that much, whereas individuals who use internet for social networking, or gaming may seek for novelty. Different from the results related to problematic internet use, novelty seeking predicted problematic smartphone use. This difference may be due to various new types of applications that are offered by smartphones in addition to internet access and also frequent updates of smartphone applications, and easy access compared to tablets and laptops, which may attract novelty seeker's attention (Cha \& Seo, 2018).

In this study, experiencing emotion regulation difficulties did not predict the problematic internet and smartphone use. This finding was inconsistent with previous literature (Whang et al., 2003; Yu et al. 2013). However, if individuals use internet and smartphones as a way to reduce their adverse feelings and anxiety as stated in cognitive-behavior model (Spada et al., 2008), then problems in emotion regulation may not be that overt to predict problematic internet and smartphone use. Therefore, future studies may focus on exploring the effects of emotion regulation in the long run. Additionally, most of the previous studies were conducted with university students (e.g. Beranuy et al., 2009; Hormes, Kearns, \& Timko, 2014; Oktan, 2011), who were more vulnerable to emotion regulation problems and perceived daily stress as more disruptive and threatening because of their age group's characteristics (e.g., Charles \& Almeida, 2007; Orgeta, 2009). Therefore, significant findings related to emotion regulation difficulties in those studies may have emerged due to the aforementioned sample characteristics. Additionally, the effect of age was controlled in the study, due to that, age-related emotion regulation problems might have become silent.

In conclusion, social anxiety and depression symptoms as well as low self-control were predictors of both problematic internet and smartphone use. Novelty seeking only predicted problematic smartphone use whereas difficulties in emotion regulation predicted neither of the dependent variables. The goal of the present study was to compare problematic Internet and smartphone use in terms of possible predictor factors in Turkish culture. The findings of the study can be evaluated both in terms of therapeutic process and prevention programs. Regarding therapy settings, therapists especially working with clients who have depression and social anxiety symptoms should check for internet and smartphone use habits. Regarding the fact that internet and smartphones are interwoven in our daily lives, checking them as possible risk factors for addiction may be overlooked. Apart from that, considering the high rates of internet and smartphone use (Turkish Statistical Institute, 2015), it becomes clear that prevention programs related to problematic use of internet and smartphone would be beneficial. These kinds of prevention programs should check risk factors like comorbidity with depression and social anxiety; low self-control and novelty seeking also give information about the possible disadvantages of misuse.

This study has some limitations. First, the data was acquired from a non-clinical sample and it cannot be generalized to the clinical population. Also, the gender composition of the sample was predominantly female. Future research that is conducted with both clinical sample and with a more even gender composition would provide more informative results. 


\section{References}

Addessi, E., Paglieri, F., \& Focaroli, V. (2011). The ecological rationality of delay tolerance: Insights from capuchin monkeys. Cognition, 119, 142-147.

Akın, A., Arslan, S., Arslan, N., Uysal, R., \& Sahranç, Ü. (2015). Self-control management and internet addiction. International Online Journal of Educational Sciences, 7(3), 95-100.

Alden, L. E., \& Bieling, P. (1998). Interpersonal consequences of the pursuit of safety. Behaviour Research and Therapy, 36(1), 53-64.

American Psychiatric Association (2013). Diagnostic and statistical manual of mental disorders (5th ed.). Washington, DC: American Psychiatric Association.

Andersson, G. (2009). Using the internet to provide cognitive behavior therapy. Behavior research and therapy, 47(3), 175-180.

Bakken, I., Wenzel, H., Gotestam, K., Johansson, A., \& Oran, A. (2009). Internet addiction among Norwegian adults: A stratified probability sample study. Scandinavian Journal of Psychology, 50(2), 121-127.

Beck, A. T., Ward, C. H., Mendelson, M., Mock, J., \& Erbaugh, J. (1961). An inventory for measuring depression. Archives of General Psychiatry, 4, 561- 571.

Beranuy, M., Oberst, U., Carbonell, X., \& Chamarro, A. (2009). Problematic internet and mobile phone use and clinical symptoms in college students: The role of emotional intelligence. Computers in Human Behavior, 25, 1182-1187.

Bergmark, K. H., Bergmark, A., \& Findahl, O. (2011). Extensive internet involvement - addiction or emerging lifestyle? International Journal of Environmental Research and Public Health, 8(12), 4488-4501.

Bian, M., \& Leung, L. (2014). Linking loneliness, shyness, smartphone addiction symptoms, and patterns of smartphone use to social capital. Social Science Computer Review, 33(1), 61-79.

Bianchi, A. \& Phillips, J. G. (2005). Psychological predictors of problem mobile phone use. Journal of Cyberpsychology \& Behavior, 8(1), 39-51.

Boyraz, G., Zhu, Y., \& Aarstad-Martin, S. (2019). The Brief Self-Control Scale: Measurement invariance across gender and relationship with academic achievement. Canadian Journal of Behavioural Science / Revue canadienne des sciences du comportement, 51(3), 201-206.

Caplan, S. E. (2002). Problematic internet use and psychosocial wellbeing: Development of a theory-based cognitive-behavioral measurement instrument. Computers in Human Behavior, 18, 553-575.

Caplan, S. E. (2003). Preference for online social interaction: A theory of problematic internet use and psychosocial well-being. Communication Research, 30(6), 625-648.

Caplan, S. E. (2007). Relations among loneliness, social anxiety, and problematic internet use. Cyberpsychological Behavior, 10(2), 234-42.

Caplan, S. E. (2010). Theory and measurement of generalized problematic internet use: A two-step approach. Computers in Human Behavior, 26, 1089-1097.

Caplan, S. E., \& High, A. C. (2011). Online social interaction, psychosocial well-being, and problematic internet use. In Young, K. S., de Abreu, C.N., (Eds.), Internet addiction: a handbook and guide to evaluation and treatment (pp. 35-53). Hoboken, NJ: John Wiley.

Ceyhan, E., Ceyhan, A. A., Gürcan, A. (2007). The validity and reliability of the problematic internet usage scale. Educational Sciences: Theory \& Practice, 7(1), 411-416. 
Cha, S.S., \& Seo, B. K. (2018). Smartphone use and smartphone addiction in middle school students in Korea: Prevalence, social networking service, and game use. Health Psychology Open, 5(1) 2055102918755046. Doi: 10.1177/2055102918755046.

Charles, S. T., \& Almeida, D. M. (2007). Genetic and environmental influences on the occurrence and perceived severity of daily stressors: More evidence for greater variation in later life. Psychology and Aging, 22(2), 331-340.

Cho, S. C., Kim, J. W., Kim, B. N., Lee, J. H., \& Kim, E. H. (2008). Biogenetic temperament and character profiles and attention deficit hyperactivity disorder symptoms in Korean adolescents with problematic internet use. Cyberpsychology \& Behavior, 11(6), 735-737.

Chou, C. \& Hsiao, M. (2000). Internet addiction, usage, gratification and pleasure experience: The Taiwan college student's case. Computers \& Education, 35, 65-80.

Clark, D. M. \& Wells, A. (1995). A cognitive model of social phobia. In R. Heimberg, M. Liebowitz, D. A. Hope, \& F. R. Schneier (Eds.), In social phobia: Diagnosis, assessment and treatment. (pp. 69-93). New York: Guilford Press.

Cloninger, C. R., Przybeck, T. R., Svrakic, D. M., \& Wetzel, R. D. (1994). The temperament and character inventory (TCI): A guide to use development and use. St. Louis, MO: Center for Psychobiology of Personality, Washington University.

Çuhadar, C. (2012). Exploration of problematic internet use and social interaction anxiety among Turkish pre-service teachers. Computers \& Education, 59, 173-181.

Dalbudak, E., Evren, C., Aldemir, S., Coşkun, K. S., Uğurlu, H., \& Yıldırım, F. G. (2013). Relationship of internet addiction severity with depression, anxiety, and alexithymia, temperament and character in university students. Cyberpsychology, Behavior \& Social Networking, 16(4), 272-278.

Darçın, A. E., Köse, S., Noyan, C. O., Nurmedov, S., Yilmaz, O., \& Dilbaz, N. (2016). Smartphone addiction and its relationship with social anxiety and loneliness. Behaviour \& Information Technology, 35(7), 520-525.

Darçın, A. E., Noyan, C., Nurmedov, S., Yılmaz, O. \& Dilbaz, N. (2015). Smartphone addiction in relation with social anxiety and loneliness among university students in Turkey. European Psychiatry, 30(1), 505.

Davis, R. A. (2001). A cognitive-behavioral model of pathological internet use. Computers in Human Behavior, 17, 187-195.

Demirci, K., Akgönül, M., \& Akpınar, A. (2015). Relationship of smartphone use severity with sleep quality, depression, and anxiety in university students. Journal of Behavioral Addictions 4(2), 85-92.

Demirci, K., Orhan, H., Demirdaş, A., Akpınar, A., \& Sert, H. (2014). Validity and reliability of the Turkish version of the smartphone addiction scale in a younger population. Bulletin of Clinical Psychopharmacology, 24(3), 226-234.

Erwin, B. A., Turk, C.L., Heimberg, R. G., Fresco, D.M., \& Hantula, D. A. (2004). The internet: home to a severe population of individuals with social anxiety disorder? Journal of Anxiety Disorders, 18(5), 629-646.

Gámez-Guadix, M. (2014). Depressive symptoms and problematic internet use among adolescents: Analysis of the longitudinal relationships from the cognitive-behavioral model. Cyberpsychology, Behavior, and Social Networking, 17, 714-719.

Gámez-Guadix, M., Orue, I., \& Calvete, E. (2013). Evaluation of the cognitive-behavioral model of generalized and problematic internet use in Spanish adolescents. Psicothema, 25, 299-306.

Gratz, K. L. \& Roemer, L. (2004). Multidimensional assessment of emotion regulation and dysregulation, factor structure, and initial validation of the difficulties in emotion regulation scale. Journal of Psychopathology and Behavioral Assessment, 26 (1), 41-47. 
Günüç, S. (2015). Relationships and associations between video game and internet addictions: Is a tolerance a symptom seen in all conditions. Computers in Human Behavior, 49, 517-525.

Hisli, N. (1988). Beck depresyon envanterinin geçerliliği üzerine bir çalışma. Psikoloji Dergisi, 6, 118-122.

Hormes, J. M., Kearns, B., \& Timko, C. L. (2014). Craving Facebook? Behavioral addiction to online social networking and its association with emotion regulation deficits. Addiction, 109, 2079-2088.

Janiri, L., Martinotti, G., Dario, T., Schifano, F., \& Bria, P. (2007). The gamblers' temperament and character inventory (TCI) personality profile. Substance Use and Misuse, 42(6), 975-984.

Karaaziz, M., \& Keskindağ, B. (2015). "I love my smartphone": A review study of smartphone addiction and related psychological risk factors. Journal of Dependence, 16(2), 78-85.

Kim, E. J., Namkoong, K., Ku, T., \& Kim, S. J. (2008). The relationship between online game addiction and aggression, self-control and narcissistic personality traits. European Psychiatry, 23(3), 212-218.

Kim, H-K, \& Davis, K. E. (2009). Toward a comprehensive theory of problematic internet use: Evaluating the role of self-esteem, anxiety, flow, and the self-rated importance of internet activities. Computers in Human Behavior, 25, 490-500.

Kim, N. S., \& Lee, K. E. (2012). Effects of self-control and life stress on smartphone addiction of university students. Journal of the Korea Society of Health Informatics and Statistics, 37(2), 72-83.

Ko, C. H., Yen, J. Y., Chen, C. C., Chen, S. H., Wu, K., \& Yen, C. F. (2006). Tridimensional personality of adolescents with internet addiction and substance use experience. The Canadian Journal of Psychiatry, 51(14), 887-893.

Ko, C.H., Yen, J.Y., Chen, C.S., Yeh, Y.C., \& Yen, C.F (2009). Predictive values of psychiatric symptoms for internet addiction in adolescents: A 2-year prospective study. Archives of Pediatrics and Adolescent Medicine, 163(10), 937-943.

Köse, S., Sayar, K., Ak, İ., Aydın, N., Kalelioğlu, N., Kırpınar, İ., ... Cloninger, C. R. (2004). Mizaç ve karakter envanteri (Türkçe TCI): Geçerlik, güvenirliği ve faktör yapısı. Klinik Psikofarmakoloji Bülteni, 14(3), 107-131.

Kwon, M., Lee, J. Y, Won, W. Y., Park, J. W., Min, J. A., Hahn, C., ... Kim, D. J., (2013). Development and validation of a smartphone addiction scale (SAS). PLoS One, 8(2), 1-7.

La Rose, R., Lin, C. A. \& Eastin, M. S. (2003). Unregulated internet usage: Addiction, habit, or deficient self-regulation? Media Psychology, 5, 225-253.

Lee, B.W., \& Stapinski, L. A. (2012). Seeking safety on the internet: Relationship between social anxiety and problematic internet use. Journal of Anxiety Disorders, 26(1), 197-205.

Li, S. M., \& Chung, T. M. (2006). Internet function and internet addictive behavior. Computers in Human Behavior, 22(6), 1067-1071.

Li, J.B., \& Vazsonyi, A. T. (2019). The utility of joint use of the Low Self-Control Scale and the Brief SelfControl Scale in explaining adolescent deviance. European Journal of Criminology. https://doi.org/10.1177/1477370819845745.

Liebowitz, M. R. (1987). Social phobia. Modern Problems of Pharmacopsychiatry, 22, 141-173.

Lin, M. P., Ko, W. U., \& Wu, J., Y. (2011). Prevalence and psychosocial risk factors associated with internet addiction in a nationally representative sample of college students in Taiwan. Cyberpsychology Behavior and Social Networking, 14(12), 741-746.

Manapat, P. D., Edwards, M. C., MacKinnon, D. P., Poldrack, R. A., \& Marsch, L. A. (2019). A Psychometric Analysis of the Brief Self-Control Scale. Assessment. https://doi.org/10.1177/1073191119890021

McKenna, K. Y. A., \& Bargh, J. A. (2000). Plan 9 from cyberspace: The implications of the internet for personality and social psychology. Personality and Social Psychology Review, 4(1), 57-75. 
McKenna, K. Y. A., Green, A. S., \& Gleason, M. E. J. (2002). Relationship formation on the internet: What's the big attraction? Journal of Social Issues, 58(1), 9-31.

Meerkerk, G. J., van den Eijnden, R. J. J. M., Franken, I. H. A., \& Garretsen, H. F. L. (2010). Is compulsive internet use related to sensitivity to reward and punishment, and impulsivity? Computers in Human Behavior, 26(4), 729-735.

Mischel, W. (2014). The marshmallow test: Understanding self-control and how to master it. Random House.

Morrison, C., \& Gore, H. (2010). The relationship between excessive internet use and depression: A questionnaire-based study of 1319 young people and adults. Psychopathology, 43(2), 121-126.

Munoz-Rivas M.J., Fernandez, L. \& Gamez-Guadix, M. (2010). Analysis of the indicators of pathological internet use in Spanish university students. The Spanish Journal of Psychology, 13, 697-707.

Ni, X., Yan, H., Chen, S., \& Liu, Z. (2009). Factors influencing internet addiction in a sample of freshmen university students in China. Cyberpsychology \& Behavior, 12(3), 327-330.

Odac1, H. (2011). Academic self-efficacy and academic procrastinations as predictors of problematic internet use in university students. Computers \& Education, 57(1), 1109-1113.

Oktan, V. (2011). The predictive relationship between emotion management skills and internet. Social Behavior and Personality, 39(10), 1425-1430.

Orgeta, V. (2009). Specificity of age differences in emotion regulation. Aging and Mental Health, 13(6), 818-826.

Park, N., \& Lee, H. (2012). Social implications of smartphone use: Korean college students' smartphone use and psychological well-being. Cyberpsychology, Behavior \& Social Networking, 15(9), 491-497.

Rapee, R. M., \& Heimberg, R. G. (1997). A cognitive-behavioral model of anxiety in social phobia. Behavior Research and Therapy, 35(8), 741-756.

Roberts, J. A., Pullig, C., \& Manolis, C. (2015). I need my smartphone: A hierarchical model of personality and cell-phone addiction. Personality and Individual Differences, 79, 13-19.

Rosati, A. G., Stevens, J. R., Hare, B., \& Hauser, M. D. (2007). The evolutionary origins of human patience: Temporal preferences in chimpanzees, bonobos, and human adults. Current Biology, 17, 1663-1668.

Rothbaum, F., Weisz, J. R., \& Snyder, S. S. (1982). Changing the world and changing the self: A twoprocess model of perceived control. Journal of Personality and Social Psychology, 42, 5-37.

Ruganci R.N. \& Gençöz T. (2010). Psychometric properties of a Turkish version of the difficulties in emotion regulation scale. Journal of Clinical Psychology, 66(4), 442-455.

Sheeks, M. S. \& Birchmeier, Z. P. (2007). Shyness, sociability, and the use of computer-mediated communication in relationship development. Cyberpsychology and Behavior, 10(1), 64-70.

Shepherd, R. M., \& Edelmann, R. J. (2005). Reasons for internet use and social anxiety. Personality and Individual Differences, 39, 949-958.

Soykan, Ç., Devrimci-Özgüven, H., \& Gençöz, T. (2003). Liebowitz social anxiety scale: The Turkish version. Psychological Reports, 93, 1059-1069.

Spada, M. M., Langston, B., Nikcevic', A.V., \& Moneta, G. B. (2008). The role of metacognitions in problematic internet use. Computers in Human Behavior, 24(5), 2325-2335.

Tangney, J. P., Baumeister, R. F., \& Boone, A. L. (2004). High self-control predicts good adjustment, less pathology, better grades, and interpersonal success. Journal of Personality, 72, 271-322.

Thomee, S., Harenstam., A., \& Hagberg, M. (2011). Mobile phone use and stress, sleep disturbances, and symptoms of depression among young adults - prospective cohort study. BMC Public Health, 11(66), $1-11$. 
Turkish Statistical Institute (2015). Information and Communication Technology (ICT) Usage Survey in Households and by Individuals. Retrieved from http://www.turkstat.gov.tr/PreTablo.do?alt id=1028.

Weinstein, A. \& Lejoyeux, M. (2010). Internet addiction or excessive internet use. The American Journal of Drug and Alcohol Abuse, 36, 277-283.

Whang, L. S., Lee, S., \& Chang, G. (2003). Internet over-users' psychological profiles: A behavior sampling analysis on internet addiction. CyberPsychology and Behavior, 6(2), 143-150.

Yen, J. Y., Ko, C. H., Yen, C. F., Wu, H. Y., \&Yang, M. J. (2007). The comorbid psychiatric symptoms of internet addiction: Attention deficit and hyperactivity disorder (ADHD), depression, social phobia, and hostility. Journal of Adolescent Health, 41, 93-98.

Young, K. S. (1996). Internet addiction: The emergence of a new clinical disorder. CyberPsychology and Behavior, 1(3), 237-244.

Yu, J. J., Kim, H., \& Hay, H. (2013). Understanding adolescents' problematic internet use from a social/cognitive and addiction research framework. Computers in Human Behavior, 29(6), 26822689. 